\title{
Study on the Innovative Application of Flipped Classroom in College Ideological and Political Theory Class
}

\author{
Qiu Yeming \\ Bohai University, Liaoning, Jinzhou 121013 \\ (Department of Finance and Commerce, Bohai University, Liaoning, Jinzhou 121013)
}

\begin{abstract}
Keywords: Flipped classroom; Teacher-student interaction; Knowledge transformation
\end{abstract}
\begin{abstract}
The planned schooling hours of the ideological and political theory course at colleges and universities are divided into two parts with the 6-4 ratio under the "flipped classroom" teaching mode. $60 \%$ of the schooling hours are used for classroom teaching and are also called the internal classroom of the first classroom; 40\% schooling hours are used for students' personalized learning and ability training, etc. and are also called the external classroom of the first classroom. (One) theoretical teaching and solving practical issues are not combined in single ideological and political educational means. (Two) large-classroom teaching is not conducive to effective interaction between teachers and students. (Three) the "flipped classroom" teaching mode is innovatively applied in the ideological and political course at colleges and universities, so the score of ideological and political course consists of end-term exam (40\%), small-class discussion (35\%) and end-term literature analysis in groups (25\%). Therefore, students are one of the key nodes of information flow. For example, asking questions, preview, class participation, quizzes and project demonstration account for $10 \%$ of usual scores respectively, which can be adjusted as needed. Therefore, a mobile microphone can be added at classroom to support students to speak.
\end{abstract}

\section{Introduction}

The basic task of higher education is to help people establish morality standards and focusing on ideological and political theory is the requirement of moral education, which can be considered as the its calling and at the same time is the responsibility as well as the mission of higher education. On December 7 2016, the CPC Central Committee General Secretary and State President and CMC Chairman, Xi Jingping delivered an important speech on The Annual Conference of Ideological and Political Education. He stressed that the ideological and political education is related to the fundamental issue of cultivating what kind of talents and how to cultivate talents and who is going to cultivate those talents.

Only when applying proper teaching mode in college ideological and political education, and focusing on establishing moral standards as the core, can we implement ideological and political education in the whole process of education to finally innovate higher education from all-round perspectives.

\section{The Theoretical and Practical Value of Innovative Application of Flipped Classroom in College Ideological and Political Class}

The Teaching Mode of Flipped Classroom. Flipped classroom is put forth according to the talents cultivation targets of Bohai University based on social constructivism in the premise of scientifically referring to Trump's teaching, flipped classroom, mass open online course, micro learning recourse and pad class etc. In addition, the implementation of flipped classroom will inevitably help students to cultivate their thinking ability, innovative ability and practical ability.

To begin with, we should schedule the learning plan in proportion with $60 \%$ and $40 \% .60 \%$ time is used for class teaching, which can be deemed as in class room while $40 \%$ time is used for individualized learning and ability training, namely after-class activities.

Secondly, we can schedule the teaching time based on what is knowledge, what is knowledge for, 
how can we use knowledge etc. What's more, we still divide it based on $60 \%$ and $40 \%$. The $60 \%$ is used for explaining what is knowledge while $40 \%$ is used for interactive activities and practice to help students understand what is knowledge for and how to use it. It breaks the traditional teaching mode of knowledge imparting, which integrates knowledge mastering and comprehensive abilities and can realize the reconstruction of the whole education system, teaching activities and process.

The Theoretical Meaning and Practical Value of Innovative Application of Flipped Classroom in Ideological and Political Class. The innovative application of flipped classroom in ideological and political class is beneficial to make the classroom lively and at the same time improve the teaching effect. It is the requirement of strengthening and advancing the ideological and political education as well as the requirement to implement quality education and promote the all-round development of college students. What's more, it can also be deemed as the guarantee to implement the education strategies, comprehensively deepen reform and realize moral education.

The research on ideological and political teaching mode aims to improve the quality and effectiveness of the class teaching. In practice and application, we can find out that education should keep up with the development of era to make the education be targeted and practical. Based on that, we are able to provide reference for the future development and help to understand the ideological state of colleges students. Therefore, we can better understand the needs of college students and help them better understand and accept Marxist theory, adhere to socialism belief, improve their abilities to analyze and solve problems to finally promote the ideological and political education with empirical evidence.

\section{Problems of College Ideological and Political Class's Theoretical Teaching Mode}

Single Ideological and Political Teaching does Not Realize the Combination of Theory and Practice. In recent years, ideological and political education in Liaoning has been improved a lot while the outcome is not ideal. In addition, due to the economic globalization and diversification of information, the economic composition and organization form of Liaoning have also changed greatly. What's more, peoples' life has gradually been westernized, and they prefer to think on their own while the benefits relation becomes more and more prominent. As a result, students do not have strict beliefs and their values faded gradually. Accordingly, the value distortion and responsibility shortage will definitely affect the healthy growth of students. In this situation, traditional ideological and political education mode is not able to integrate theoretical teaching as well as practice and cannot achieve expected results, which also ignores responsibility education, psychological education, and team spirit cultivation. So, some students have prominent psychological problems and they are not capable of applying Marxist theory to solve their psychological issues. Based on this, we have to break the traditional teaching mode and explore new teaching modes with promotion so as to improve the ideological and political education level.

Large Class Teaching is Not Beneficial to Efficient Interaction. In 17th century, Comenius Johann Amos elaborated the idea of class teaching in Great Didactic ${ }^{[1]}$. In addition, Gu Mingyuan pointed out the disadvantages of class teaching in Dictionary of Education: the main disadvantage of traditional class is that it can not be adapted to the individual difference as well as characteristics of students ${ }^{[2]}$. We can conclude that the traditional class teaching which is used to play a pivotal role cannot adapt to the modern time and the voice of carrying out education reform is getting louder and louder.

The large class teaching mode is having more and more problems in terms of college ideological and political education. For example, teachers cannot teach students in accordance with their aptitude, and cannot help them to develop themselves and help them to cultivate innovative as well as practical abilities. Currently, the ideological and political education in Liaoning is single which is always cramming education based on big class with about 200 students and sometimes it is more than 200 students in one class. Therefore, advanced teaching philosophy cannot be realized and students do not participate a lot in class so the teaching quality is not ideal. Therefore, in order to improve the efficient effectiveness of ideological and political class of Liaoning, it is necessary to dig deep into its teaching mode and carry out discussion in class and conduct flipped class teaching. 


\section{The Innovative Application of Flipped Classroom in College Ideological and Political Education}

Modern True Plan: Organically Combine Large Class Teaching, Small Group Discussion and Independent Learning. Trump plan emerged in 20 century and was established by Lloyd Trump. He planned to combine large class teaching with small group discussion and independent learning based on flexible time rather than fixe time. Large class teaching is for excellent teachers to adopt modern teaching means for parallel class. Afterwards, group discussion will discuss about the contents in large class based on a group with 15 to 20 students. Then, students will carry out independent learning, research and homework. The teaching time is divide into: $40 \%$ large class teaching, 20\% small group discussion and 40\% independent learning.

In large class teaching, the relation between teachers, teacher assistant and students can be considered as a pyramid relation. In large classes, teachers mainly impart key knowledge. In small group discussion, the relation between teachers and students is equal. Student Nie Yafang once said that, when individuals are equal, there is space for students to show their personalities, which will encourage them to think independently and learn independently.

Small group discussion asks students to deeply read at least 200 pages per week. In terms of question setting, it is not only about academic meaning, but also raising students' interests. So, the ideological and political exam result should be composed of $40 \%$ final result, $35 \%$ small group and $25 \%$ independent literature analysis. Among which, the small group discussion should be give by teacher assistant while the final analysis should be given by judges on spot.

Teacher assistants participating in small group discussion are made up of teachers, instructors and administrative staffs. On one hand, they act as organizers and judges and on the other hand, they are be friends of students and influence them with their profession and passion to finally realize full participation.

In order to realize the innovative application of flipped classroom in college ideological and political education, we have to organize the space system made up pf teachers, students and environment into an organic system for them to be evolved and updated. The most important point is to help with the information flow, which can help to remove the barriers and give relative environment and technology support.

Help with the Textbook Information Flow Based on Tasks. The text books include history, statistical methodology, concept, judgment etc. However, not all the textbook information can flow. Only when students and teachers participate in tasks to communicate, can we help with the information flow.

Therefore, we should help with the ideological and political information flow while not changing the large class teaching mode. What's more, teachers should continually challenge students based on different tasks so as to ignite their thinking ability; according to learning objects, we can also design flexible tasks and ask students to complete the tasks and share with each other.

Help Students to Understand Better. Even if teachers are willing to carry out interactive activities, students might not cooperate. Therefore, the information flow is the key point. According to the analysis of the previous chapter, the reason why students do not take the initiative to cooperate is that they do not have the habit of independent thinking.

The solution is to let students know how they will carry out a class, which is similar to entrance education and aims to let them know that flipped class is a routine and the main contents include the following:

The important meaning and simple techniques of raising a question. The important meaning of raising a question can be concluded by a sentence of Einstein. He once said 'The mere formulation of a problem is far more essential than its solution, which may be merely a matter of mathematical or experimental skills. To raise new questions, new possibilities, to regard old problems from a new angle requires creative imagination and marks real advances in science.' Simple techniques of raising a question includes: ask why, do not judge, be skeptical, relate things together etc. During the learning process, the most simple way is to question and ask do I really understand? When we get a book, we should ask ourselves what are the basic questions we are going to learn and how we 
are going to answer and what kind of conclusions can we get. Furthermore, what have we learned and what I have not mastered yet. Based on this, it will be much easier for us to raise a question, which can also ignite questions.

The Meaning and Operation of Pre-Class Preparation. Teaching materials, especially the materials for students from Normal Universities are related to learning. As long as you prepare before class, it will be easy to raise a question. For example, we are studying everyday, but what are we learning every day? How can we define it? Those kind of questions are popular ones in terms of psychology and education. The reason why students do not have questions is that they do not prepare before class and think independently. During the teaching process, teachers should mention the main focus to students first and ask them to prepare in advance so that teachers can check the outcome. While preparing, students should take advantage of techniques and raise a large sum of questions. In fact, while carrying out learning, students are asked to go through a process of 'prestudy, in class teaching, reviewing, and exam'. However, most of them have skipped this process and most of college teachers do not take it as a must. Recently, people gradually realize that it is wrong to ignore the complete process. University of Macau runs based on the systems of United Kingdom and United States of America, and it highlights the complete learning process a lot. Every week, there will be assignment and reading materials along with quiz as well as project demonstration. By comparison, we will know that our learning way is not correct. College studying is not only about listening, we have to make a lot of efforts.

Guarantee positive participation based on assessment system. Students' negative participation is due to the shortage of compulsory rules and they think they will get the same result no matter what they do. The flipped classroom will focus on the assessment process and guarantee the positive participation of students. It will highlight question raising, pre-class preparation, class participation, quiz, and project demonstration and the result can drive them to study. For example, those above assessment methods can get $10 \%$ regular results and can be added into total results with proper adjustment.

Seek for the support of advanced technology. During class teaching, the adoption of audio, microphone and internet play important roles, which can also contribute to a successful and lively classroom.

Audio. The quality of audio plays a significant role. While teachers are on stage, they do not realize how important it is because they rarely pay attention to it. However, when they sit there as students, they can see it clearly. In some of the classrooms, it is very difficult to listen carefully because the sound is too faint to hear and students cannot hear their teachers clearly.

Microphone. The microphone is always installed in a fixed position, which actually limits the moving range of teachers. Sometimes, the position is far away from the computer. On the other hand, the number of microphone is limited and students cannot hear the one who is going to give their voice. So, how can we convey information successfully? Based on this situation, we should properly add the numbers of microphone to support students to give their voice.

Internet technology support. In the internet era, it is not wise to ignore the function of the internet. For example, we can develop an app and put the questions on that app for students to answer. What's more, we can summarize the questions in seconds. That is to say, with the assistance of APP, we can collect their information quickly. Based on that, we can send out information and get information feedback. In fact, it is easy to put this into reality and the focus is whether we have confidence and determination or not.

\section{References}

[1] Johann Amos, Great Didactic[M]. Beijing: Educational Science Publishing House, 2015:36.

[2] Gu Mingyuan. Dictionary of Education[M].Shanghai: Shanghai Education Publishing House, 1990:207. 